\title{
Dynamics of a parasite assemblage of the Vermilion Rockfish Sebastes miniatus from northwestern Baja California, México
}

\author{
M. A. Rodríguez-Santiago • J. A. Rosales-Casián • \\ M. I. Grano-Maldonado
}

Received: 12 September 2013/Revised: 9 February 2014/ Accepted: 11 March 2014/Published online: 25 March 2014

(c) Springer-Verlag Berlin Heidelberg and AWI 2014

\begin{abstract}
A parasite assemblage of Sebastes miniatus from northwestern Baja California, México, was composed of a total of 12 species: five ectoparasites (two monogeneans and three parasitic copepods) and seven endoparasites (two digeneans, one cestode, three nematodes, and one acanthocephala). Five of these parasites constituted new genera records to the genus Sebastes, and nine were new geographic records. The most abundant species were the endoparasites Parabothriocephalus sagitticeps, Hysterothylacium sp., and Anisakis sp., and the specific richness ranged from 1 to 8 parasite species per host. The most important parasite species in terms of prevalence were Microcotyle sebastis (93\%) and Anisakis sp. (92\%). The mean abundance of parasites found in S. miniatus showed significant variations over the year, with maximum values
\end{abstract}

Communicated by K. T. Jensen.

M. A. Rodríguez-Santiago $(\varangle)$

Instituto de Ciencias del Mar y Limnología, Unidad Académica Mazatlán, Universidad Nacional Autónoma de México, Joel Montes Camarena s/n, 82040 Mazatlán, Sinaloa, Mexico

e-mail: amparor@cicese.mx; amparoshalom@hotmail.com

M. A. Rodríguez-Santiago

Facultad de Ciencias Marinas, Universidad Autónoma de Baja California, Km 106 Carretera Tijuana-Ensenada, Ensenada, BC, Mexico

J. A. Rosales-Casián

División de Oceanología, Departamento de Ecología Marina, Centro de Investigación Científica y de Educación Superior de Ensenada BC, Ensenada, BC, Mexico

M. I. Grano-Maldonado

Departamento de Ecofisiología, Facultad de Ciencias del Mar, Universidad Autónoma de Sinaloa, Paseo Claussen s/n, A.P. 610, Mazatlán, Sinaloa, Mexico
(31.7 individuals/host) in August, and minimum (0.39 individuals/host) in February. $P$. sagitticeps showed the highest mean intensity of infection (190.4 parasites/host), followed by Anisakis sp. (127.2 parasites/host) and Hysterothylacium sp. (46.6 parasites/host). The presence of larval stages of the nematodes Anisakis, Pseudoterranova, and Hysterothylacium is particularly important due to their high abundance and prevalence and because they may represent a human health risk (anisakiasis). Rockfishes (family Scorpaenidae) of the genus Sebastes constitute one of the most important groundfish resources in the American and Mexican northern Pacific Ocean, both for recreational and for the commercial fisheries of California and Baja California. These rockfish species makes up a substantial part of the Mexican cuisine.

Keywords Mexico $\cdot$ Sebastes miniatus $\cdot$ Metazoan parasites $\cdot$ Helminths

\section{Introduction}

In the northwestern coasts of Mexico, the vermillion rockfish, Sebastes miniatus, Jordan and Gilbert 1880 (Scorpaenidae), is a highly valued marine fish species for its white meat, and it is caught all year by the coastal commercial and the recreational fishing (Siri-Chiesa and Moctezuma-Hernández 1989; Elorduy-Garay and RuizCórdova 1998; Rosales-Casián and González Camacho 2003; Rodríguez-Santiago and Rosales-Casián 2008). Currently, few parasite studies in marine fishes from the Mexican Pacific coasts are available, and particularly in Baja California. The identification of parasite species and the community description at northern Baja California have been conducted in other different six rockfish species of the 
genus Sebastes (Alvarado-Villamar and Ruiz-Campos 1992), also in the California halibut Paralichthys californicus (Castillo-Sánchez et al. 1998), and in the ocean whitefish, Caulolatilus princeps (Rodríguez-Santiago and Rosales-Casián 2011).

The rockfishes from the Pacific coast of North America are conformed by at least by 65 species; however, the greatest diversity (56 species) is found within the Southern California Bight (Love et al. 2002). This fish group comprised a large proportion in the coastal fisheries catch of Baja California (Rodríguez-Medrano 1993; HernándezHernández 2002; Rosales-Casián and González Camacho 2003), and California, USA (Eschmeyer et al. 1983; Love 1996; Stephens et al. 2006).

The vermillion rockfish $S$. miniatus is found from the Prince William Sound in south Alaska to central Baja California. They inhabit rocky reefs, kelp forests, and canyons at depths of 15-467 m, but are commonly found at 50-150 m (Love et al. 2002; O'Connell et al. 1992). The vermillion rockfish represents a potential intermediate host for many parasites, and the prey of a final host like the California sea lion (Lowry et al. 1991). However, in spite of its economic importance and its role as a staple in the local diet, no studies describing the parasite assemblage of S. miniatus at Baja California have been conducted. Therefore, the aim of the present work was (1) to determine the assemblage of parasite species in the red rockfish S. miniatus, (2) to determine the prevalence, abundance, and intensity of parasite infection across 1 year, (3) to determine the habitat (organ) preferences of the parasite species, and (4) to determine the relationships between parasite abundance and host size, condition factor, and water temperature.

\section{Materials and methods}

Vermillion rockfish specimens were bimonthly obtained from sportfishing catches (during 2005) at San Quintín bay and adjacent areas, Baja California, México (between $30^{\circ} 29^{\prime} 52^{\prime \prime} \mathrm{N}-116^{\circ} 07^{\prime} 54^{\prime \prime} \mathrm{W}$ and $30^{\circ} 20^{\prime} 25^{\prime \prime} \mathrm{N}-115^{\circ} 59^{\prime} 20^{\prime \prime} \mathrm{W}$ ) (Fig. 1). A total of 210 individuals with a range of 210-610 $\mathrm{mm}$ total length were analyzed. The sea surface temperature was provided by the boat captains, and temperatures from 50 to $140 \mathrm{~m}$ depth were obtained from the IMECOCAL monitoring program of Centro de Investigacion Cientifica y de Educacion Superior de Ensenada (CICESE) (García-Córdova et al. 2005).

All vermillion rockfish individuals were measured for total length using an ictiometer $(\mathrm{mm})$ and weighed $(\mathrm{g})$ with a digital balance Accu-Lab. The Fulton's Condition Factor (KLP) was calculated as $K=$ [W/TL3] 10,000, where: $W=$ weight $(\mathrm{g})$ and $\mathrm{TL}=$ total length $(\mathrm{mm})$, to describe the physiological condition of each individual fish (Ricker 1975).

The specimens were examined for external parasites on skin and fins. They were then dissected, and the internal organs were transported on ice to the laboratory for examination under a stereoscopic microscope to collect parasites (gill cavity, intestinal cecum, mesentery, coelomic cavity, stomach wall, stomach, intestine, and gall bladder).

Helminths were fixed in AFA (acetic acid-formaldehyde-alcohol) solution for 2-24 h. Then, they were preserved in ethyl alcohol (70 \%) and stained with Gomori's trichromic stain. Nematodes were fixed in Berland's liquid, preserved in ethyl alcohol (70\%), and cleared with a solution of phenol-ethanol (Lent's solution) and mounted on slides covered with glycerin-gelatin. Copepods were first fixed in ethyl alcohol $(70 \%)$, and then, they were
Fig. 1 Location of the study area at San Quintín, Baja California, Mexico

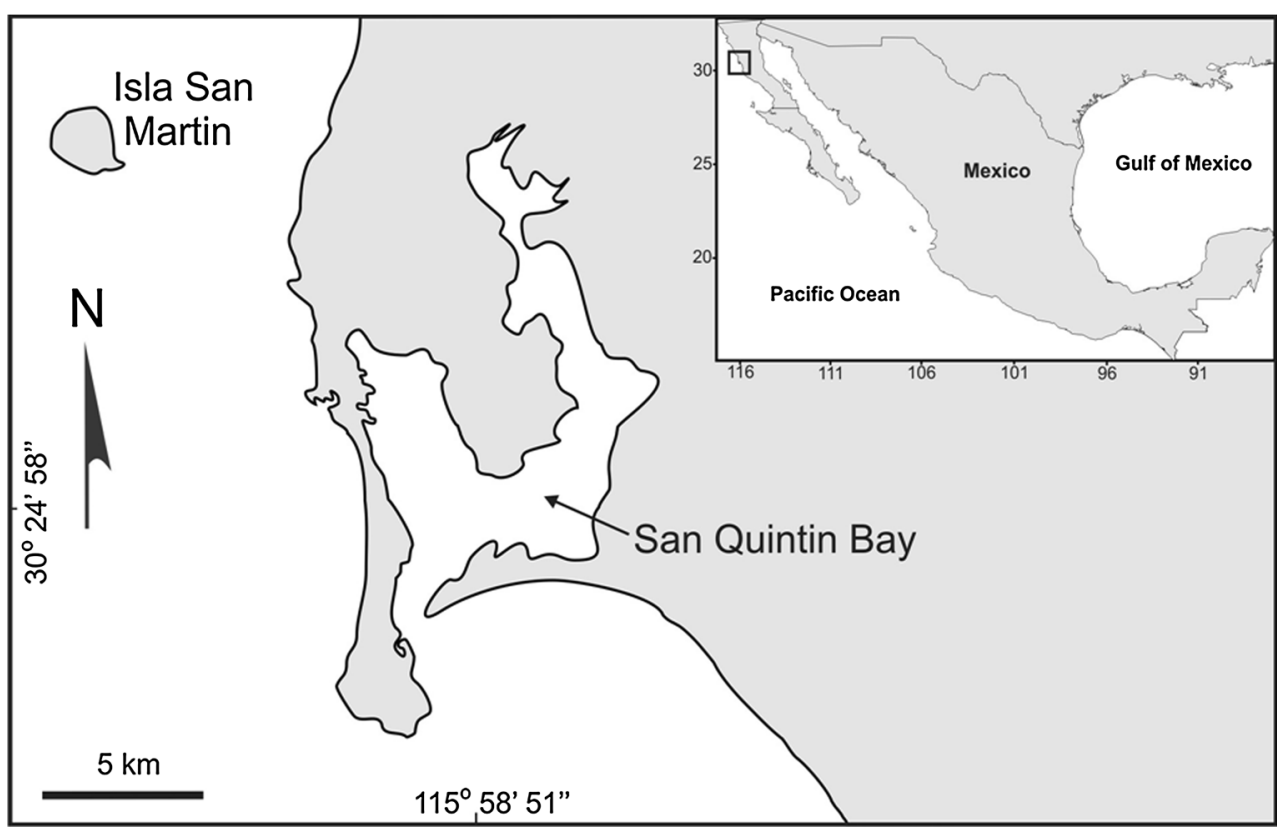


cleared using a solution of glycerin-alcohol and mounted on slides covered with glycerin-gelatin (Yamaguti 1961).

After obtaining the morphological data, identification of helminths was identified according to keys proposed by Yamaguti (1963); Vidal-Martínez et al. (2002); Yamaguti (1971); Bravo-Hollis (1967, 1982a, b); Mendoza-Garfias and Pérez-Ponce de León (1998); Kuchta et al. (2008); Yamaguti (1961); and Anderson et al. (1974-1983) for nematodes. To identify the parasitic copepods, keys of Cressey and Boyle-Cressey (1980, 1985); Kabata (1979, 1992a, b); and Boxshall (2004) were used.

Species richness, prevalence $(\%)$, abundance (parasite number/host), and intensity (parasite number/infected hosts) of parasites were determined according to Bush et al. (1997). The presence of parasite species in the different internal organs was used as habitat preferences. Due to the nonnormal distribution of the parasitological data and heteroscedasticity of variances, nonparametric analyses were used. To assess significant variations in parasite abundance over time, a Kruskal-Wallis (KW) one-way analysis of variance was performed for each parasite species (Steel and Torrie 1986). Spearman rank correlations were used to assess relationships between the parasite abundance and the host size and weight, fish condition, and seawater temperature.

\section{Results}

At the San Quintín fishing area, the sea surface temperature averaged $( \pm \mathrm{SE}) 16.0 \pm 0.3{ }^{\circ} \mathrm{C}$. The highest temperature $\left(18.2 \pm 0.5^{\circ} \mathrm{C}\right)$ was in August, and the lowest $\left(14.9 \pm 0.3{ }^{\circ} \mathrm{C}\right)$ in February. At the fishing depth of $50-140 \mathrm{~m}$, the average annual temperature was $10.9 \pm 0.09^{\circ} \mathrm{C}$ with higher values in October $\left(11.5 \pm 0.20^{\circ} \mathrm{C}\right)$ and lower in June $\left(10.2 \pm 0.08^{\circ} \mathrm{C}\right)$.

From the 210 individuals of vermillion rockfish, a total of 29,640 parasites were found belonging to 12 species (from which, eight were identified to species level and the rest to genus). Cestodes were the most abundant group with $50.3 \%$ of the total (Table 1). The identified species were seven endoparasites (two digeneans, one cestode, three larval stages of nematodes, and one acanthocephalan) and five ectoparasites (two monogeneans and three copepods) (Table 2). The digeneans, cestodes, acanthocephalan, and ectoparasites were found in adult stage.

The most infested organs were the stomach, pyloric cecum, and intestine, with a presence of seven species (Table 2). Larvae of the nematode Hysterothylacium sp. showed less organ specificity; they were found in most organs within the host (mesentery, stomach, pyloric cecum, and intestine). Trematodes and cestodes were mainly restricted to the digestive tract (mainly in the stomach). The acanthocephalan species were found only in the mesentery. Ectoparasites were abundant in the gill cavity, except Benedenia derzhavini, which was also frequent in the skin and fins (Table 2).

All the fish examined were parasitized with a minimum of three individuals of copepods to a maximum of 6,373 cestodes (Table 1). In general, the most abundant parasite species was Parabothriocephalus sagitticeps $\quad(14,879$ individuals), followed by Hysterothylacium sp. (6,373 ind), Anisakis sp. (3,942 ind), and M. sebastis (2,696 ind) (Table 2). The highest abundance of parasites was detected in August, and the lowest in December (Fig. 2a). Six of the 12 species recorded (M. sebastis: Kruskal-Wallis, $p=0.000 ; B$. derzhavini: $\mathrm{KW}, \quad p=0.035 ; N$. escorpaenae: $\mathrm{KW}$, $p=0.002 ;$ Clavellostis sebastidis: $\mathrm{KW}, p=0.000 ;$ Corynosoma strumosum: $\mathrm{KW}, p=0.000$ and Anisakis sp.: $\mathrm{KW}$, $p=0.001)$ showed temporal variations in their abundance (Fig. 2a). Also, the overall mean abundance of parasites showed significant variations $(\mathrm{KW}, p=0.047)$ over the year.

The species with higher values of prevalence were $M$. sebastis (92.6\%), Anisakis sp. (91.8\%), and Hysterothylacium sp. (60.1\%) (Fig. 2b). Consequently, these

Table 1 Groups and total number of parasites recorded in Sebastes miniatus caught on the coasts of San Quintín, B.C., Mexico

\begin{tabular}{|c|c|c|c|c|c|c|c|c|}
\hline & \multirow[t]{2}{*}{ Hosts } & \multicolumn{4}{|c|}{ Endoparasites } & \multicolumn{3}{|l|}{ Ectoparasites } \\
\hline & & Digeneans & Nematodes & Cestodes & Acanthocephales & Monogeneans & Copepods & Total \\
\hline Feb & $15(25-29)$ & 7 & 627 & 622 & 105 & 128 & 3 & 1,507 \\
\hline Apr & $28(25.5-28)$ & 25 & 1,071 & 1,688 & 49 & 557 & 26 & 3,444 \\
\hline Jun & $62(37-61)$ & 23 & 4,589 & 6,073 & 231 & 997 & 40 & 12,015 \\
\hline Aug & $35(32-48)$ & 16 & 1,465 & 2,401 & 302 & 499 & 11 & 4,729 \\
\hline Oct & $29(30-48.5)$ & 5 & 1,011 & 1,940 & 229 & 395 & 46 & 3,655 \\
\hline Dec & $41(30-55)$ & 17 & 1,560 & 2,155 & 206 & 406 & 54 & 4,439 \\
\hline Total & 210 & 93 & 10,323 & 14,879 & 1,122 & 2,982 & 180 & 29,789 \\
\hline$\%$ & & 0.3 & 34.9 & 50.3 & 3.8 & 10.1 & 0.6 & 100.0 \\
\hline
\end{tabular}

Groups of endoparasites (digeneans, nematodes, cestodes, acanthocephales) and ectoparasites (monogeneans and copepods). In brackets the size range of the fish in $\mathrm{cm}$ 
Table 2 Parasite species found in Sebastes miniatus $(n=210)$

Organ preference, prevalence $(\% P)$, mean abundance (MA),

Location in the body of the host: * larval stage, $F$ fins, $S$ skin, $G C$ gill cavity, $I C$ intestinal cecum, $M e$ mesentery, $C C$ coelomic cavity, Stw stomach wall, $S$ stomach, $I$ intestine, $G$ gall bladder

Fig. 2 a Average abundance (parasites/host $\pm \mathrm{SE}$ ) and $\mathbf{b}$ prevalence $(\%)$ of parasites on specimens of Sebastes miniatus collected at San Quintín, Baja California, from February to December 2005 mean intensity (MI)

\begin{tabular}{lllrrrr}
\hline & Species & Organ & Total & $\% P$ & MA & \multicolumn{2}{c}{ MI } \\
\hline Digenea & Fellidostomum sebastodis & G & 28 & 11.2 & $0.3 \pm 0.2$ & $1.1 \pm 0.1$ \\
& Parahemiurus merus & S, I & 65 & 17.9 & $0.6 \pm 0.4$ & $1.5 \pm 0.3$ \\
Cestoda & Parabothriocephalus & S, I, IC & 14,879 & 32.8 & $80.8 \pm 33.4$ & $190.4 \pm 48.1$ \\
& sagitticeps & & & & & \\
Nematoda & Anisakis sp.* & CC, Stw, I, & 3,942 & 91.8 & $15.0 \pm 3.9$ & $15.8 \pm 4.1$ \\
& & Me & & & & \\
& Hysterothylacium sp.* & Me, S, I & 6,373 & 60.1 & $37.9 \pm 18.0$ & $46.6 \pm 18.1$ \\
& Pseudoterranova sp.* & S, Me, I, IC & 8 & 2.9 & $0.2 \pm 0.2$ & $0.6 \pm 0.3$ \\
Mcanthocephala & Corynosoma strumosum & Me, CC, I & 1,112 & 37.5 & $5.3 \pm 1.8$ & $13.3 \pm 4.4$ \\
& Microcotyle sebastis & GC & 2,696 & 92.6 & $11.2 \pm 2.7$ & $11.6 \pm 3.0$ \\
Copepoda & Benedenia derzhavini & S, F, GC & 286 & 40.9 & $1.7 \pm 0.5$ & $2.8 \pm 0.6$ \\
& Lepeoptheirus sp. & GC, S, F & 67 & 15.8 & $0.5 \pm 0.3$ & $1.5 \pm 0.2$ \\
& Clavellostis sebastidis & GC & 60 & 18.8 & $0.5 \pm 0.2$ & $1.2 \pm 0.4$ \\
& Neobranchia scorpaenae & GC & 53 & 15.5 & $0.4 \pm 0.2$ & $1.1 \pm 0.4$ \\
\hline
\end{tabular}
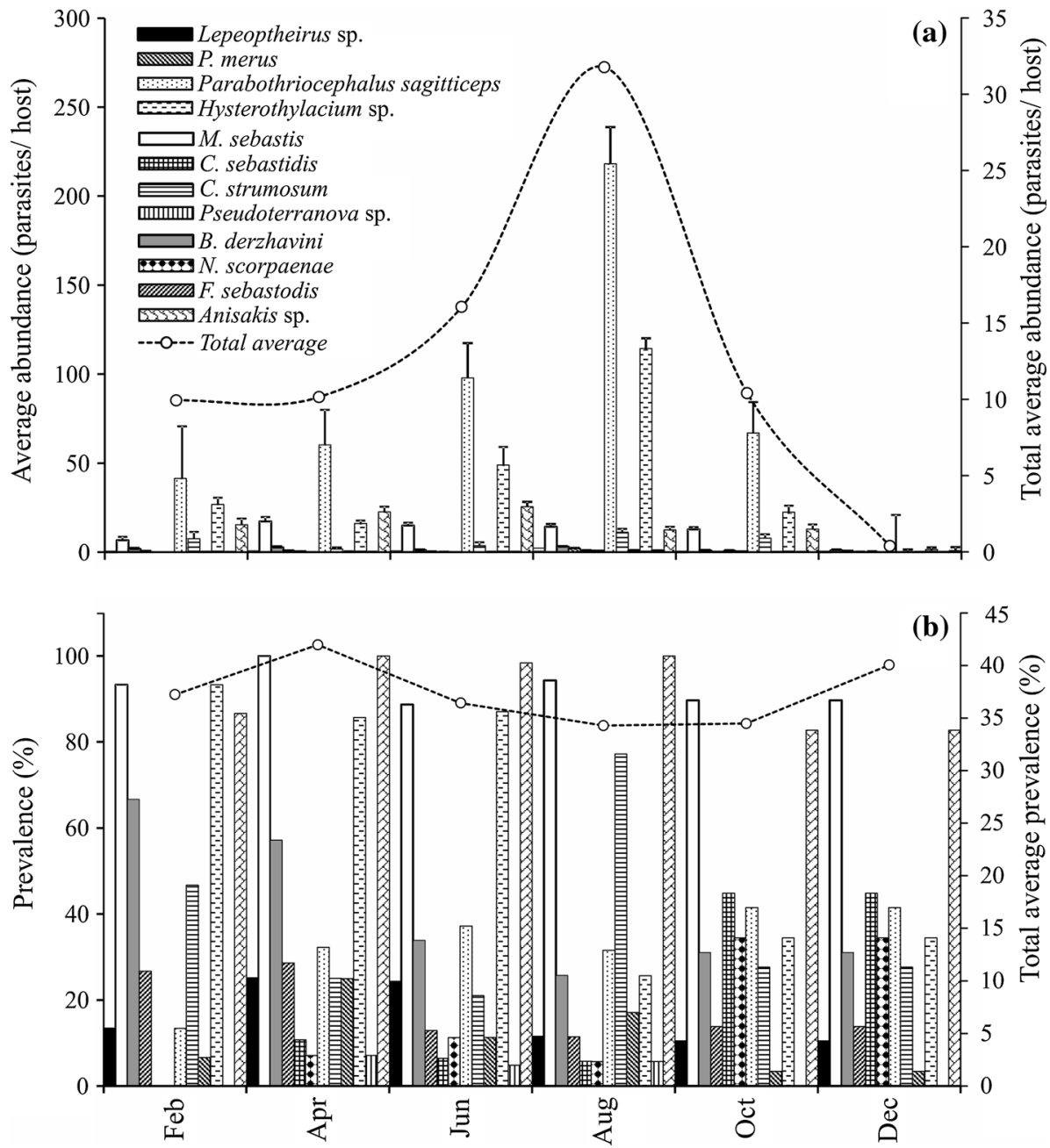

three were identified as the most common species of the parasite assemblage in $S$. miniatus. The rest of the species had prevalences lower than $60 \%$.

From late spring to autumn (April-October), Anisakis sp. showed a prevalence of $100 \%$ and a decrease (80 \%) in early winter (December) (Fig. 2b). Similarly, M. sebastis sp. exhibited prevalences of up to $90 \%$ across the year. The species B. derzhavini, C. strumosum, and C. sebastidis showed a decrease in prevalence from spring to summer of 40.6, 16, and $39.2 \%$, respectively (Fig. 2b). 
The species with highest intensity was $P$. sagitticeps (average intensity $=190.4 \pm 48.1$ ) followed by Anisakis sp. $(15.8 \pm 4.1)$ and Hysterothylacium sp. (46.6 \pm 18.1$)$ (Table 2). There were not significant changes in the overall mean intensity of parasites throughout the year. The intensity was higher in February and lower in December.

A significant positive correlation (Spearman rank) was found between the prevalence and the average abundance of parasites $(R=0.73, p=0.000)$, indicating that the species with high values of prevalence were also the most abundant. Nonsignificant correlations between abundance of parasites and total length $(R=0.1033, p=0.134)$, weight $(R=0.196, p=0.087)$, condition of fish $(R=$ $-0.0108, p=0.876)$, or bottom temperature $(R=-0.103$, $p=0.6004)$ were found.

\section{Discussion}

In the present study, a total of 12 parasite species were identified for $S$. miniatus. Three of them (M. sebastis, Anisakis sp., and Pseudoterranova sp.) had already been reported for this rockfish in the coasts of California, USA (Love et al. 2002; Love and Moser 1983), while the other nine species constitute new parasites for this host and a new locality record.

Rockfishes of the genus Sebastes sp. from the Southern California Bight (western coast of Baja California, México, and California, USA) are composed of 56 species and are a potential intermediate host for many parasites (Love et al. 2000; González and Acuña 1998). This rockfish species reach $76 \mathrm{~cm}$ in length, $6.8 \mathrm{~kg}$ in weight, and up to 60-year old (Leet et al. 1992; Love et al. 2002). According to Love (2002), females grow larger than males and probably live longer. It has also been found that $50 \%$ of these fish reach sexual maturity at 5 years $(37 \mathrm{~cm})$ (Love 2002). The specimens collected in this study ranged in length from 21 to $61 \mathrm{~cm}$, indicating that different age groups were included.

In this study, nematodes and parasitic copepods were the most diverse groups (three species of each). However, compared with other studies, this diversity was relatively low. For example in $S$. alutus from the coasts of California, eight species of nematodes and 12 species of copepod species were recorded (Love et al. 2000). Larvae of Anisakis sp. and Hysterothylacium sp. have been recorded from most of the fishes studied in the Mexican Pacific coasts, as well as in many pelagic and demersal fishes from other areas of the world (Aranda-Cruz 2006; Laffon-Leal et al. 2000). The percentage of $S$. miniatus specimens infected by Anisakis larvae was relatively high (prevalence $=91.8 \%$ ) in comparison with that reported in other congeneric species (Sebastes capensis, 2.9-4.8\%) (Domínguez Ortega et al. 2001).
Differences in parasite prevalences between Sebastes species and other fishes can probably be explained by differences in the diet and environmental conditions. Furthermore, previous studies have suggested that parasites may be present in a locality when hosts are available, and when the specific abiotic conditions that allow the survival of the infective stages are present (Guidelli et al. 2003).

The parasite species richness in this rockfish was relatively low in comparison with other congeneric species. In S. nebulosus (from southeastern Pacific), a richness of 26 parasite species was reported and was mostly composed by digeneans (Holmes 1990). In S. capensis (from northern Chile) and $S$. caurinus (from the Atlantic and Pacific oceans), a richness of 16 and 50 parasite species was reported, respectively (Olsen 1952; González 1998). Also, in $S$. serranoides (a species that also distributes from Oregon, USA, to Baja California, Mexico), the species richness was of 36 species, which was positively related to the host age and size (Love et al. 1984). Although the parasite abundance in $S$. miniatus showed certain seasonality, it was not related to the weight and length of the fish or ocean water bottom temperature during our study period. Variations in abundance could be due to other factors such as prey availability over the year. The diet of $S$. miniatus includes a variety of species (fishes, skids, octopuses, shrimps, copepods, isopods, polychaetes, etc.), many of which are potential hosts for initial stages of cestodes (Rojas-Herrera et al. 2003). Similarly, adult stages of parasites also inhabit predators such as elasmobranches (Schmidt 1986) and sea lions (Lowry et al. 1991). In this respect, $S$. miniatus is a part of an intermediate food web permitting the parasites to reach their maturity in the final host (Love et al. 2002; Jensen 2001). Some parasites found in $S$. miniatus (digeneans, cestodes, nematodes, and acanthocephalans) are possibly transmitted via ingestion of larval forms or by the presence of free-living stages of larvae in the plankton, which often determines the parasitic fauna of the host (Dogiel 1964). Monogeneans and parasitic copepods can be acquired by being in contact with other intermediate hosts such as fish and crustaceans. Only the monogenean Microcotyle sebastis is specific in this fish group. All the parasite species found in this study, except nematodes, were found in adult stage, suggesting that fish are used as definitive host. Nematodes generally use marine mammals as definitive host (Aguayo and Maturana 1973).

The lack of correlation between the parasite abundance and the host size could also be because specimens of $S$. miniatus were limited to a size range $(24-68 \mathrm{~cm}$ total length). Similar findings have been documented in other studies, where there is no significant relationship between the host body size and the abundance of parasites (Dogiel 1964; Rhode et al. 1994; Stromnes and Andersen 1998). For example, in $S$. capensis from Talcahuano, southern Chile, 
the lack of correlation was attributed to the small sample size $(n=26)$ and the narrow size range $(16.5-35.5 \mathrm{~cm}$ total length) of fish collected in their study (Balboa and GeorgeNascimento 1998). A study in S. capensis from Coquimbo Bay, northern Chile, documented nine helminth species from 180 red rockfish captured (González and Acuña 2000). In that study, the abundances of Pseudopecoelus sp. and Anisakis sp. were significantly and positively correlated with the size of $S$. capensis, while Corynosoma sp. correlated negatively with host size (González and Acuña 2000). Moreover, in a parasitological study conducted on six species of Sebastes ( $S$. constellatus $14-43 \mathrm{~cm}, n=63 ; S$. elongates $18-41 \mathrm{~cm}, n=42 ; S$. rosaceus $19-36 \mathrm{~cm}$, $n=33$; S. umbrosus $15-47 \mathrm{~cm}, n=41 ;$ S. helvomaculatus $18-55 \mathrm{~cm}, n=26$; and $S$. chlorostictus $17-31 \mathrm{~cm}, n=15$ ) from the North-Occidental coast of Baja California, the authors found that the host size was not a relevant variable to explain variations in the intensity of infection (AlvaradoVillamar and Ruiz-Campos 1992). However, studies in Sebastes fasciatus (from the Scotia Shelf) revealed that the size of the host had little effect on parasite prevalence, except for Anisakid species, where smaller fish feed more heavily on the intermediate host of the parasite than do larger fish (Scott 1988). Thus, it is possible that other factors (e.g., the sexual maturity stage, changes in the diet, the ingest volume, or the contact possibilities with other intermediate hosts) may be involved in this lack of correlation (Muñoz and Cribb 2005).

Some parasite species of S. miniatus showed microhabitat specificity for intestine, stomach, and blind sacs. This could be because they find there a high availability of nutrients and low competition for resources (Stromnes and Andersen 1998). Thus, the specificity for certain microhabitats could also help determine the community structure of parasites in S. miniatus (Sasal et al. 1999). This specificity for organ host was similar to those reported in $S$. capensis (from the southeastern Pacific) (González and Acuña 1998).

Similar to other congeneric species, in the present study there was a predominance of certain groups of parasites of the genera $P$. sagitticeps, Hysterothylacium, Anisakis, Microcotyle, and Corynosoma (González and Acuña 1998). In S. serranoides, larval cestodes were predominant (Love et al. 1984). In other species from Baja California ( $S$. constellatus, S. elongatus, S. rosaceus, S. umbrosus, S. helvomaculatus, and $S$. chlorosticus), the predominant group was the nematode Anisakis (65-90\% of prevalence), followed by digeneans (4.1-25\% of prevalence) (Alvarado-Villamar and Ruiz-Campos 1992).

The presence of larvae of Anisakis sp. and Hysterothylacium sp. was particularly important because in addition to being relatively abundant and causing diseases in the fish host, they may constitute a risk factor to human health (Anisakiasis). These parasites can infect humans by eating marinated raw fish, 'ceviche or cebiche' (LaffonLeal et al. 2000), which is a popular seafood dish in the coastal regions of the Americas, especially Central and South America. Therefore, we recommend avoiding consumption of raw or inadequately cooked fish. Species of the genera Anisakis and Pseudoterranova are more commonly found causing Anisakiasis, but other species of the family Anisakidae (e.g., Contracaecum, Hysterothylacium, and Raphidascaris) do too (Chai et al. 1986).

In conclusion, the magnitude of infection (abundance, prevalence, and intensity) in this host supports previous findings that demersal fishes are rich in the number of individual parasites (Holmes 1990) and that they have a parasitic fauna represented mainly by helminths (cestodes, nematodes, and monogeneans). In this study, the importance of analyzing the parasitic fauna of commercially important fish species has been highlighted, in addition to contributing to the knowledge of marine biodiversity, because it reports parasite species that can represent a potential risk for human health.

Acknowledgments This study was supported by the internal project of CICESE: Analysis of the recreative-sport fishing catches from San Quintín, B.C., Mexico, and by the project: Baseline study of the nearshore non-reef fishes of Bahía de Los Angeles, Baja California, México, prior to proposed development, funded by the UCMEXUSCONACYT grant. Rodríguez-Santiago thanks to CONACYT by the financial support (Grant). Thanks to Emma Fajer (CIAD-Unidad Mazatlan), Gorgonio Ruiz (UABC), Sharon Herska, and Ernestina Castro (CICESE) by providing us materials and equipment in their respective laboratories. We are grateful to Karen Englander (Faculty of Languages, University of Baja California) for her English review and editing of the manuscript.

\section{References}

Aguayo A, Maturana R (1973) Presencia del lobo marino (Ottaria flavescens) en el litoral chileno. Arica $\left(18^{\circ} 27^{\prime} \mathrm{S}\right)$ a Punta Maiquillahue $\left(39^{\circ} 27^{\prime} \mathrm{S}\right)$. Biol Pesq Chile 6:45-75

Alvarado-Villamar MR, Ruiz-Campos G (1992) Estudio comparativo del grado de infección de macroparásitos en seis especies de Sebastes (Pisces Scorpenidae) de la costa Noroccidental de Baja California, México. Cienc Mar 18:79-92

Anderson RC, Chabaud AG, Willmott S (1974-1983) CIH keys to the nematode parasites of vertebrates. Commonwealth Agricultural Bureaux: Farnham Royal, Bucks, England, Vol 1-10

Aranda-Cruz C (2006) Platelmintos parasitos de la "Sarangola" Microlepidotus brevipinnis Steindachner, 1869 (Haemulidae) de la Bahia de Chamela Jalisco. Dissertation MSc Thesis. Universidad Nacional Autonoma de México, p 31-34

Balboa L, George-Nascimento M (1998) Variaciones ontogenéticas y entre años en las infracomunidades de parásitos metazoos de dos especies de peces marinos de Chile. Rev Chil Hist Nat 71:27-37

Boxshall GA (2004) An introduction to copepod diversity. The Ray Society, London 940

Bravo-Hollis M (1967) Helmintos del Pacífico mexicano XXV. Descripción de tres monogéneos del Golfo de California. An Inst Biol UNAM 37:107-123 
Bravo-Hollis M (1982a) Helmintos de peces del Pacífico mexicano XXXVII. Sobre seis especies conocidas de monogéneos del Suborden Microcotylinea Lebedev, 1972. An Inst Biol UNAM 52:1-12

Bravo-Hollis M (1982b) Helmintos de peces del Pacífico mexicano XXXIX. Estudio de Monogéneos del suborden Microcotylinea Levedev, 1972, con la presentación de una subfamilia y una especie nuevas. An Inst Biol UNAM 52:13-26

Bush A, Lafferty K, Lotz J, Shostak A et al (1997) Parasitology meets ecology on its own terms: Margolis, revisited. J Parasitol 83:575-583

Castillo-Sánchez E, Rosales-Casián JA, Pérez-Ponce de León G (1998) Helminth parasites of Paralychtys californicus (Osteichthyes: Paralichthydae) in Estero de Punta Banda, Todos Santos Bay and San Quintín Bay, Baja California, México. Cien Mar 24:443-462

Chai JY, Chu YM, Sohn WM, Lee SH (1986) Larval Anisakids collected from the yellow corvina in Korea. Korean J Parasitol 24:1-11

Cressey R, Boyle-Cressey H (1980) Parasitic copepods of Mackerel and tuna-like fishes (Scombridae) of the world. Smithson Contr Zool 311:54-61

Cressey R, Boyle-Cressey H (1985) Holobomolochus (Copepoda: Bomolochidae) redefined, with descriptions of three new species from the Eastern Pacific. J Crustac Biol 5:717-727

Dogiel VA (1964) General parasitology. Oliver and Boyd, London 164

Domínguez Ortega J, Alonso-Llamazares A, Rodríguez L, Chamorro M, Robledo T, Bartolomé JM, Martínez Cócera C (2001) Anaphylaxis due to hypersensitivity to Anisakis simplex. Int Arch Allergy Immnol 125:86-88

Elorduy-Garay JF, Ruiz-Córdova SS (1998) Age, growth, and mortality of Caulolatilus affinis (Osteichthyes: Branchiostegidae) from the Southern Gulf of California. Pac Sci 52:259-272

Eschmeyer WN, Herald ES, Hammann H (1983) A field guide to Pacific Coast fishes of North America. Houghton Mifflin, Boston $336 \mathrm{p}$

García-Córdova J, Robles-Pacheco JM, Gómez-Valdés J (2005) Informe de datos de CTD. Campaña IMECOCAL 0501/02. B/O Francisco de Ulloa. Enero 21-Febrero 10 de 2005. Informe Técnico, Departamento de Oceanografía Física, CICESE, p 132

González L (1998) The life cycle of Hysterothylacium aduncum (Nematoda: Anisakidae) in Chilean marine farms. Aquaculture 162:173-186

González MT, Acuña E (1998) Metazoan parasites of the red rockfish Sebastes capensis off northern Chile. J Parasitol 84:783-788

González MT, Acuña E (2000) Influence of host size and sex on the endohelminth infracommunities of the red rockfish Sebastes capensis off northern Chile. J Parasitol 86:854-857

Guidelli GM, Isacc A, Takemoto RM, Pavanelli GC (2003) Endoparasite infracommunities of Hemisorubim platyrhynchos (Valenciennes, 1840) (Pisces: Pimelodidae) of the Bahia River, up Paraná River floodplain, Brazil: specific composition and ecological aspects. Braz J Biol 63:261-268

Hernández-Hernández A (2002) Composición específica de los peces escama comercializados en el Mercado de Mariscos del Puerto de Ensenada, Baja California, México. Facultad de Ciencias Biológicas, Universidad Autónoma del Estado de Morelos. Cuernavaca, Morelos (México), pp 60

Holmes JC (1990) Helminth communities in marine fishes. In: Esch G, Bush A, Aho J (eds) Parasites communities: patterns and processes. Chapman \& Hall, London, pp 101-130

Jensen K (2001) Four new genera and five new species of lecanicephalideans (Cestoda: Lecanicephallidea) from elasmobranchs in the Gulf o California, Mexico. J Parasitol 87:845-861

Kabata Z (1979) Parasitic copepoda of British fishes. Ray Society, London 468
Kabata Z (1992) Copepods parasitic on fishes: keys and notes for identification of the species. Synopses of the British Fauna (New Series) No. 47. Universal Book Services/W. Backhuys: Oegstgeest. ISBN 90-73348-16-1. VII, pp 264

Kabata Z (1992b) Copepoda parasitic on Australian fishes, XV. Family Ergasilidae (Poecilostomatoida). J Nat Hist 26:47-66

Kuchta R, Scholz T, Bray RA (2008) Revision of the order Bothriocephalidea Kuchta, Scholz, Brabec and Bray, 2008 (Eucestoda) with amended generic diagnoses and keys to families and genera. Syst Parasitol 71:81-136

Laffon-Leal SM, Vidal-Martínez V, Argora-Torres G (2000) Ceviche a potential source of human anisakiasis in Mexico? J Helmintol 74:151-154

Leet WS, De Wees CM, Haugen CW (1992) California's living marine resources and their utilization. California Sea Grant, UCSGEP 92-12

Love MS (1996) Probably more than you want to know about the fishes of the Pacific coast. Really Big Press, Santa Barbara 215

Love MS, Moser M (1983) A checklist of parasites of California, Oregon and Washington marine and estuarine fishes. NOAA technical report, NMFS SSRF-777, pp 576

Love MS, Shiner K, Morris P (1984) Parasites of olive rockfish, Sebastes serranoides (Scorpaenidae) off central California. US Fish B Noaa 82:530-573

Love MS, Caselle E, Snook L (2000) Fish assemblages around seven oil platforms in the Santa Barbara channel area. Fish B Noaa 98:96-117

Love MS, Yoklavich M, Thorsteinson L (2002) The rockfishes of the Northeast Pacific. University of California Press, Los Angeles 405

Lowry MS, Stewart BS, Heath CB, Yochem PK (1991) Seasonal and annual variability in the diet of California sea lions Zalophus californianus at San Nicolas Island, California, 1981-1986. Fish B Noaa 89:331-336

Mendoza-Garfias B, Pérez-Ponce de León G (1998) Microcotílidos (Monogenea: Microcotylidae) parásitos de peces marinos de la Bahía de Chamela, Jalisco México. An Inst Biol UNAM 69(2):139-153

Muñoz G, Cribb T (2005) Infracomunity structure of parasites of Hemigymnus melapterus (Pisces: Labridae) from Lizard Island, Australia: the importance of habitat and parasite body size. J Parasitol 91:38-44

O’Connell VA, Gordon DA, Hoffmann A, Hepler K (1992) Northern range extension of the vermilion rockfish (Sebastes miniatus). Calif Fish Game 78:173

Olsen SL (1952) Some nematodes parasitic in marine fishes. Intitute of Marine Science. (University of Texas) Vol 2: pp 174-215

Rhode KC, Hayward C, Gosper D (1994) A tropical assemblage of ectoparasites: gill and head parasites of Lethrinus miniatus (Teleostei: Lethrinidae). Int J Parasitol 24:1031-1053

Ricker WE (1975) Computation and interpretation of biological statistics of fish populations. Bull Fish Res Can 191:1-382

Rodríguez-Medrano MC (1993) Descripción y análisis de la pesca deportiva en Bahía de Todos Santos, Ensenada, B. C. Dissertation MSc Thesis, Centro de Investigacion Cientifica y de Educacion Superior de Ensenada, Mexico, p 88

Rodríguez-Santiago MA, Rosales-Casián JA (2008) Abundance and size composition of vermilion rockfish Sebastes miniatus (Jordan and Gilbert 1880), from sport fishing catches of San Quintín, Ensenada, Baja California, Mexico. Bull S Calif Acad Sci 107:25-32

Rodríguez-Santiago MA, Rosales-Casián JA (2011) Parasite structure of the Ocean whitefish Caulolatilus princeps from Baja California, México (East Pacific). Helgol Mar Res 65:197-202

Rojas-Herrera AA, Mascaro M, Chiappa-Carrara X (2003) Hábitos alimenticios de los peces Lutjanus peru y Lutjanus guttatus 
(Pisces: Lutjanidae) en Guerrero, Mexico. Rev Biol Trop 52:959-971

Rosales-Casián JA, González Camacho JR (2003) Abundance and importance of fish species from artisanal fishery on the Pacific coast of Northern Baja California. Bull S Calif Acad Sci 102:51-65

Sasal P, Trouve S, Muller-Graf C, Morand S (1999) Specificity and host predictability: a comparative analysis among monogenean parasites of fish. J Anim Ecol 68:437-444

Schmidt GD (1986) CRC handbook of tapeworm identification. CRC Press, Inc., Florida 675

Scott JS (1988) Helminth parasites of redfish (Sebastes fasciatus) from the Scotian Shelf, Bay of Fundy, and eastern Gulf of Maine. Can J Zool 66:617-621

Siri-Chiesa M, Moctezuma-Hernández P (1989) La pesca de Baja California. Universidad Autónoma de Baja California, México, p 211

Steel RG, Torrie JH (1986) Bioestadística: principios y procedimientos. McGraw-Hill, México 662
Stephens J, Wendt D, Wilson-Vandenberg D, Carroll J, Nakamura R, Nakada E, Rienecke S, Wilson J (2006) Rockfish resources of the South Central California coast: analysis of the resource from party boat data, 2000-2005. Cal COFI Rep 47:140-155

Stromnes E, Andersen K (1998) Distribution of whaleworm (Anisakis simplex, Nematoda, Ascaridoidea) L3 larvae in three species of marine fish; saithe (Pollachius virens L.), cod (Gadus morhua L.) and redfish (Sebastes marinus L.) from Norwegian waters. Parasitol Res 84:281-285

Vidal-Martínez V, Aguirre-Macedo I, Sholz T, González-Solis D, Mendoza-Franco F (2002) Atlas de los helmintos parásitos de cíclidos de México. Instituto Politecnico Nacional, México D.F 183

Yamaguti S (1961) Systema helminthum. III. Nematodes. Interscience Publishers, INC, New York, p 1261

Yamaguti S (1963) Systema helminthum. Vol. IV: Monogenea and Aspidocotylea. Interscience Publishers, New York 381

Yamaguti S (1971) Synopsis of digenetic trematodes of vertebrates, Vol. I. Keigaku Publishing Co, Tokio, p 1074 